Trinity University

Digital Commons @ Trinity

Modern Languages and Literatures Faculty

Research

Modern Languages and Literatures Department

Fall 2017

\title{
Goethe's Colors: Revolutionary Optics and the Anthropocene
}

Heather I. Sullivan

Trinity University, hsulliva@trinity.edu

Follow this and additional works at: https://digitalcommons.trinity.edu/mll_faculty

Part of the Modern Languages Commons

\section{Repository Citation}

Sullivan, H.I. (2017). Goethe's colors: Revolutionary optics and the Anthropocene. Eighteenth-Century Studies, 51(1), 115-124. doi:10.1353/ecs.2017.0049

This Article is brought to you for free and open access by the Modern Languages and Literatures Department at Digital Commons @ Trinity. It has been accepted for inclusion in Modern Languages and Literatures Faculty Research by an authorized administrator of Digital Commons @ Trinity. For more information, please contact jcostanz@trinity.edu. 


\title{
GoETHE's Colors: Revolutionary OptICS AND THE ANTHROPOCENE
}

\section{Heather I. Sullivan}

Renowned poet and author Johann Wolfgang von Goethe (1749-1832) claimed that his greatest contribution to the world was not his famous Faust (Part I in 1808 and Part II in 1832) or his best-selling 1774 epistolary novel, Die Leiden des jungen Werther [Sorrows of Young Werther], the first German novel to achieve international fame, but was instead his scientific treatise on optics and colors, $\mathrm{Zur}$ Farbenlebre [Towards a Theory of Color] from 1810. In his conversations with Johann Peter Eckermann recorded in his last few years of life, Goethe declared that there always had been and would continue to be many excellent poets but that only he achieved a true understanding of colors in his lifetime:

\begin{abstract}
Auf Alles was ich als Poet geleistet habe, ...bilde ich mir gar nichts ein. Es haben treffliche Dichter mit mir gelebt, es lebten noch Trefflichere vor mir, und es werden ihrer nach mir sein. Daß ich aber in meinem Jahrhundert in der schwierigen Wissenschaft der Farbenlehre der einzige bin, der das Rechte weiß, darauf tue ich mir etwas zu gute, und ich habe daher ein Bewußtsein der Superiorität über Viele.

IIn terms of everything that I have accomplished as a poet, ...I don't have any illusions. There have been excellent poets who lived at the same time as I, and those who were even better before me, and there will be more of them after me. That I am the only one in my century who is right in the difficult science of color theory-that I do attribute to myself and I am conscious in that regard of being superior over many. ${ }^{1}$
\end{abstract}

Heather I. Sullivan is Professor of German and Comparative Literature at Trinity University in San Antonio, Texas. Her research focuses on ecocriticism, or the environmental humanities, with work on Goethe's literature and science as well as comparative studies of texts from the Anthropocene. 
Despite his global literary fame, Goethe repeatedly asserted that his long-term, hands-on experiments with light and color were his greatest achievement. For the most part, his optical experiments on light were received by his friends and the scientific community alike as amateur trifles published by a poet who inaccurately criticized the established Newtonian systems. Goethe received some acclaim for his ideas on light, clouds, and plants, and for coining the term and field of "morphology," but it was not until the twentieth century's increased understanding of the neurological processes of perception, quantum mechanics, and chaos and complexity theory that scholars began to see that Goethe's critique of Newton was not just a smattering of insights mixed in with a larger body of work based on poetic misunderstandings. I provide here a brief overview of Goethe's study of color, particularly in terms of how he sought to express the human perception and experience of it as emblematic for the human-nature interactions, or more precisely, how we engage in the material world. In short, this essay contextualizes Goethe's Theory of Color in terms of recent ecocritical work regarding the human-natural world interfaces, especially in our modern, post-Industrial Revolution, humanly inflected era of the Anthropocene.

In Goethe's thinking, colors represent the foundational explanation for all morphological and metamorphic processes of the active natural world energized by the sunlight that grow, live, and crystallize into ever new forms. Rather than focusing on static objects, Goethe saw the natural—and social—world as an expression of ongoing processes. Colors are, above all, actively developing components of a world in flux, not fixed entities. Newton, he wrote, was wrong in that he studied light as if it were an isolated feature and not an interactive part of the world. ${ }^{2}$ Newton's breakdown of white light into all the spectrum of colors is accurate, of course; what Goethe recognized, in contrast, is the more complex and muddied realm of perception and relations between and among things and observers, studied in quantum mechanics and the new materialisms. ${ }^{3}$ In other words, these fields and Goethe postulate that our physical world and human existence are part of manifold engagements between energy, matter, living things, and mental perception. We are never truly "outside" of the system that we study, though most of empirical science assumes that we are or could be or at least should strive to be when undertaking objective studies. Though one can accurately carry out precise Newtonian calculations about light and colors as if they were abstract physical characteristics comprehensible in a vacuum, Goethe insisted on studying colors within materiality composed of processes constantly influenced by their environment, and in which we human observers are also immersed. In his essay "Der Versuch als Vermittler von Objekt und Subjekt" ["The Experiment as Mediator of Object and Subject"], Goethe notes: "Da alles in der Natur, besonders aber die allgemeinern Kräfte und Elemente in einer ewigen Wirkung und Gegenwirkung sind, so kann man von einem jeden Phänomene sagen, daß es mit unzähligen andern in Verbindung stehe” [Since everything in nature, especially, however, the general forces and elements, exists in eternal action and counter-action, one can thus say of every single phenomenon that it exists in connection to innumerable others]. ${ }^{4}$

Goethe furthermore claims that scientists should avoid beginning with theories and instead view with an open mind and open eyes the things themselves, so that their "natural" characteristics and relationships can appear. In the Farben- 
lebre, Goethe describes what he understands as "natural" implications of colors. Purple/red, for example, is placed at the top of his color wheel, and provides a feeling of being satisfying as the "highest" form and is naturally symbolic for "majesty." We see the use of this idea in Goethe's Fairy Tale, in which the prince is wearing purple. Similarly, yellow is active and refreshing, the color of sunlight and daytime, whereas blue is the color of quiet, distance, and depth-of the sky and the ocean. The artistic use of such colors and the cultural trends mirror what Goethe believes to be derived from a natural order. Divining such meaning and using empirical studies are, to his thinking, interconnected practices. $\mathrm{He}$ asserts that the ideal scientific process allows things to appear in relation to other things and that we must remain constantly alert to our tendency to see ourselves rather than the world. But Goethe also believes that viewers must be "open" to what is directly in front of them. Hence, a scientist needs first of all to examine his/her own perceptual processes and assumptions. "Bei Betrachtung der Natur im Großen wie im Kleinen hab' ich unausgesetzt die Frage gestellt: Ist es der Gegenstand oder bist du es, der sich hier ausspricht?" [When viewing nature on large and small scales I have unceasingly asked the question: is it the object or is it you, that is speaking here?]. ${ }^{6}$ In previous discussions of Goethe's optics, I have studied this approach as a kind of "ecological" perspective that addresses relations among things and energy."

Goethe's Theory of Color has three main sections: didactic, polemic, and historical. In the didactic section, he documents his scientific light experiments in full detail. The polemic study parses Newton's Optics line by line, explaining the claims and science and delineating in fierce terms what are, in Goethe's view, the mistakes. The final section is a summary of historical views regarding colors beginning with ancient Greek scholars and detailing studies up through his contemporaries, a standard practice for eighteenth- and nineteenth-century scientific works. For this essay, the first section, where Goethe presents his own research, is of greatest relevance. This "didactic" study is composed of three parts, each of which emphasizes the interactive aspects of light and colors; these are what Goethe terms the "physiological," "physical," and "chemical" colors. His first category presents the physiological colors that "belong to the eye." 8 These colors occur when light rays enter our eyes and are processed by the brain and are hence not inherent to objects but rather occur as optical illusions. His examples include the colors one sees after staring at a light and then closing one's eyes or if you stare at one color for a long time and then look at a white page and see its opposite on the color wheel (from red to green or from purple to yellow, for example). Beginning with such physiological colors that come into being due to the processes of perception profoundly shifts the study of color from an abstract delineation of the thing in isolation-light, in this case-and toward a sense of human-world engagements and the human brain activity. This study is hence "anthropocentric," or humancentered, but not in the sense eschewed by ecocritics for being egotistically focused only on things that we think have value to us, but rather in a different, more material way that places human beings in the mix of materiality and studies our visual experiences in this context. Such exploration of the sensory engagement with light as the interactive process producing color has inspired much of the resurging interest in Goethe's science. ${ }^{9}$ 
Goethe labels his second category of colors as "physical," which occur due to the physics of light hitting opaque or reflective surfaces. These include the colors appearing briefly in the shimmering mother of pearl, or in the refraction of light in water or through glass. These colors result when light, perceiving beings-human, in this case-and objects interact. Light passes through materials, bends, or reflects, thereby creating brief fluctuations of shifting colors. Again, it is the engagement with the world out of which colors appear: "Physische Farben nennen wir diejenigen, zu deren Hervorbringung gewisse materielle Mittel nötig sind, welche aber selbst keine Farbe haben, und teils durchsichtig, teils trüb und durchscheinend, teils völlig undurchsichtig sein können" [Physical colors we name those, for whose production certain material means are necessary, which themselves have no color, and can be in part transparent, in part cloudy and translucent, (or) in part fully non-transparent]. ${ }^{10} \mathrm{He}$ describes them as transient, passing, non-fixed colors. Much of this section of the Farbenlebre concentrates on how light is influenced and altered by reflecting off of or passing through various materials.

Goethe's third category of colors includes the ones one might expect: the "chemical" colors that derive from the chemical physical properties of matter that absorb and reflect specific wavelengths of light, producing stable, durable colors. Still, Goethe also describes these more fixed colors as "processes" rather than final properties. "So nennen wir diejenigen [Farben], welche wir an gewissen Körpern erregen, mehr oder weniger fixieren, an ihnen steigern, von ihnen wieder wegnehmen und andern Körpern mitteilen können" [Thus we name those (colors) that we activate on certain bodies, (that we) more or less fix, intensify on them, take away from them again, and that we can impart to other bodies]. ${ }^{11}$ In short, colors emerge from differing interactions and have different lifespans and different forms according to Goethe, but all three categories involve the interaction of light, perception, and material objects. Hence Goethe correctly surmised that scientific undertakings must consider the human actors when speaking of the human experience of colors. Elsewhere, I described this interactive theory as "an ecology of color." 12

This kind of ecological understanding of optics is based on the idea that everything in nature is interconnected, and that human beings are also part of the world in which we live. In some ways, thinking in these terms helps to explain the difference between Goethe and Newton. Most scholars have noted that Goethe was wrong with his critique of Newton; specifically, Newton demonstrated that white light contains all the other wavelengths of light and hence "all" the colors. Goethe, in contrast, believed that white light is "pure" and only produces colors when it impacts an object or is refracted or reflected. Goethe was merciless in his critique, condemning Newton fervently for "blinding" his students, and of producing naught but sophisticated artifices and "fairy tales" instead of facts. Newton's work, he claimed, bordered on the unspeakable, "die ganz nah an Unredlichkeit grenzen." ${ }^{13}$ Goethe's assertions are in part based on the fact that Newton's strictly mathematical studies of light remain outside of the messy interactions of all elements of the world. In Goethe's Farbenlebre, light functions as one element that is always in conflict with darkness and things and eyes. Colors are thus not always already present but rather an outcome emerging from these endless "battles" made up by the shifting, breaking, and bending of light that is then perceived by a viewer. Light must always be understood in a context, not in the abstract: "Das Licht hingegen [im 
Vergleich mit der Finsternis] können wir uns niemals in abstracto denken, sondern wir werden es gewahr als die Wirkung eines bestimmten Gegenstandes, der sich in dem Raume befindet und durch eben diese Wirkung andere Gegenstände sichtbar macht" [Light in contrast (to darkness) we can never think of in the abstract, but rather we become aware of it as the impact of a specific object that is situated in space, and (it is) through precisely this impact that it makes other objects visible]. ${ }^{14}$

One of Goethe's main critiques of Newton's system is hence specifically that it ignores the boundaries, contexts, and conditions in which we perceive light and which influence its bending or breaking. His theory, in contrast, acknowledges such boundaries and influences:

Die Lehre dagegen, von der wir überzeugt sind, und von der ivir diesmal nur insofern sprechen, als sie der Newtonischen entgegensteht, beschäftigt sich auch mit dem weißen Lichte. Sie bedient sich auch äußerer Bedingungen, um farbige Escheinungen hervorzubringen. Sie gesteht aber diesen Bedingungen Wert und Würde zu, sie bildet sich nicht ein, Farben aus dem Licht zu entwickeln, sie sucht uns vielmehr zu überzeugen, daß die Farbe zugleich von dem Lichte und von dem, was sich ihm entgegenstellt hervorgebracht werde.

[The theory, in contrast, of which we are convinced, and of which we in this case speak only in so far as it opposes the Newtonian theory, has to do also with white light. This theory also utilizes external conditions in order to bring forth colored appearances. It gives credence, in fact, to these conditions, and does not pretend to develop colors out of light; it attempts to convince us rather that color is brought forth both from light and from that which it encounters.] $]^{\text {ss }}$

Furthermore, Newton overlooks entirely the "borders" that impact light's interactions and thereby produce colors, according to Goethe's theory: "Ein Bild entsteht nur durch Grenzen, diese Grenzen übersieht Newton ganz, ja er leugnet ihren Einfluß. Wir aber schreiben dem Bilde sowohl als seiner Umgebung, der hellen Mitte sowohl als der dunkeln Grenze, der Tätigkeit sowohl als der Schranke, in diesem Falle vollkommen gleiche Wirkung zu." [An image arises only with the borders; these borders are entirely overlooked by Newton, indeed he denies their influence. We however ascribe completely equal influence not only to the image but also its surroundings, to the bright medium as well as to the dark border, to the activity as well as to the restrictions. $]^{16}$

With some similarity to phenomenology and to Karen Barad's new materialist discussion of quantum physics in Meeting the Universe Halfway: Quantum Physics and the Entanglement of Matter and Meaning, Goethe's optics presents the assumption that perception of objects and the objects themselves are interconnected and co-creative. ${ }^{17}$ His discussion of light in the Farbenlebre formulates a plan for becoming aware of our perception itself as an active process, one that can be hindered by theories. Goethe repeatedly claimed that scientists must learn to see directly instead of imposing their assumptions on the world. ${ }^{18}$ Although Newton was right about the refractability of white light, contrary to Goethe's assumptions, Goethe's focus on human perception-or perception generally—and the scientific process inspired many scientists after him, particularly in modern physics. ${ }^{19}$ 
Goethe's contributions to optics were not his only extra-literary activity: he worked in many arenas, including the Weimar court, where he aided the Herzog Carl August by overseeing mining and forestry, and accompanying the Herzog onto the battlefield in the Napoleonic wars in 1792-93. He also spent much of his career pursuing both literary and scientific quests, including his earliest geological attentions to minerals, his botanical excursions in Italy from which he coined the term the "Urpflanze," his exploration of plant and animal forms that led him to coin the term and ground the field of "morphology," and his atmospheric study of clouds and weather at the end of his life, as well as his study of light and colors in which he infamously took Newton to task. The influence of these scientific and practical projects appears throughout his literary works, especially Faust, which directly speaks of geological issues, the elements, and the atmosphere. In terms of his Farbenlehre, we can see numerous color themes in his enigmatic Märchen [Fairy Tale] from 1895, published as the final story in his collection, Unterbaltungen deutscher Ausgewanderten. ${ }^{20}$

At the time he was working on his theory of colors, all of Europe was up in arms during the French Revolution and then the Napoleonic Wars. During Goethe's experience with Herzog Carl August in the battle against the French, he continued to write on colors, even going so far as to describe them as his own "scientific revolution."21 Instead of political violence and upheaval, however, Goethe strove for a gradual cultural change based on knowledge, insight, and learning to "see" directly and correctly. According to Eckermann's "Gespräche," Goethe claimed that those who change the world must be clever but also must be the inheritors of major mistakes which they correct, thereby shifting history: "Um Epoche in der Welt zu machen ...., dazu gehören bekanntlich zwei Dinge; erstens, daß man ein guter Kopf sei, und zweitens, daß man eine große Erbschaft tue. Napoleon erbte die französische Revolution, Friedrich der Große den schlesischen Krieg, Luther die Finsternis der Pfaffen, und mir ist der Irrtum der Newtonischen Lehre zu Teil geworden." [In order to make an epochal change in the world ..., there are two requirements, as is well-known; first, that one has a good head, and, second, that one has a significant inheritance. Napoleon inherited the French Revolution, Friedrich the Great the Silesian War, Luther the darkness of the priests, and to me came the error of the Newtonian theory. ${ }^{22}$ Goethe's science was thus, in his inind, an epochal break. While aspects of his color theory were inaccurate, Goethe's insights were, in fact, radically different.

One of his most important contributions was the emphasis on the human observer within the experiment. The human impact on scientific observation was central to his Farbenlebre but also to all of his scientific studies. Indeed, he explored the human impact on the natural world in many of his literary works as well, including Faust, who aimed to create "free land" by building an enormous dike against the sea. This final feat at the end of Part II of Goethe's famous play is still being debated: was Goethe advocating for massive reshaping of the physical world, or was he a proto-environmentalist concerned about Faust's willingness to work with Mephistopheles and use piracy and murder in order to change the physical world dramatically ${ }^{23}$ In both cases, however, Goethe described how the natural world helped shape human beings and human beings changed the natural world. Goethe, in other words, looked at nature and humanity in terms of each 
other in reciprocity and he expressed concern about the potential violence of these engagements. Perhaps not surprisingly, his assertion that he was part of an epochal change turns out to be true in this regard, rather than in terms of his proclaimed revolution in optics and color studies.

Today, there is an emerging view that this epoch during Goethe's lifespan was indeed a significant moment of transition, a time of massive epochal change, or the beginning of the Anthropocene, a new geological era demarcated by the accelerated human impact on the environment across the globe made possible by the Industrial Revolution and the steam engine. The traces of anthropogenic matter or industrial particulates now cover the entire surface of the globe, with the result that human beings now appear to function en masse as the equivalent of a geological force. ${ }^{24}$ The key feature of the Anthropocene, one that radically differs from the previously vast and slow geological epochs occurring over millions and even billions of years, is speed. Never before have large-scale changes occurred so quickly and over time (in contrast, say, to the sudden impact of asteroids hitting the earth in the past and causing global climate cooling or a volcanic eruption). That is, our modern, industrial activities are continuous and unceasing but are also so massive in impact and power that they are considered equivalent to what we usually deem "geological" forces such as plate tectonics. This era of the Anthropocene is the time of "man," though some have borrowed from Goethe and labeled it a "Faustian" era. Like Goethe's so-called "superman," Faust, the Anthropocene has been understood in a Promethean and even optimistic manner by some hopeful technophiles claiming that we can now engineer the entire planet as we wish. Many scientists and environmental scholars disagree with such Promethean views, instead understanding the Anthropocene as a negative transformation of the Earth. They express grave concern about climate change, ocean acidification, and the ensuing bleaching and death of entire coral reefs. The list of environmental crises denoted by the Anthropocene also includes the currently ongoing mass extinction event on planet earth (the sixth in the planet's history, this one caused by human development), as well as deforestation, desertification, the melting cryosphere, and the spread of toxins throughout most of our water, soil, and nutrient cycles. ${ }^{25}$ The Anthropocene is an era of rapid change spurred by technological and industrial developments, including modern scientific agriculture fed by petroleum products.

The debate surrounding this era and whether it should be accepted officially by the international stratigraphic societies continues. The term itself was coined in 2000 by the atmospheric chemist and Nobel Laureate Paul Crutzen and the biologist Eugene Stoermer in response to the environmental changes noted above, particularly the sudden increase in quantities of $\mathrm{CO}_{2}$ in the atmosphere. Crutzen and Stoermer placed the beginning of the era around 1800 , specifically at the time of James Watt's modern steam engine that was patented in $1781 .^{26}$ Some scholars argue that the Anthropocene actually began much earlier with the first development of agriculture, whereas others, like Jan Zalasciewicz, see the actual, traceable geological data emerging with twentieth-century nuclear testing and the spread of radiation and plastics across the globe. ${ }^{27}$ This essay works with the original timeframe suggested by Crutzen and Stoermer, as well as the groundbreaking environmental humanities scholars, Dipesh Chakrabarty, Rob Nixon, and Timothy Morton. ${ }^{28}$ The Anthropocene, in any case, documents a phase in Earth's history and 
human history when humankind has a changed relationship with the environment, and it is a phase beginning during Goethe's lifetime.

Goethe's optical studies and Farbenlebre are part of his overall writings that present just such an overriding sense of a changing world. Certainly, he was unaware that he was living during what we now see as the beginning of the Anthropocene. Nor could he or his contemporaries have known what the long-term impacts would be of expanding capitalism, of industrialization, of the increased speed and use of fossil fuels for transportation and most every facet of modern culture including electricity, technology, and chemical agriculture. Yet, Goethe's works repeatedly return to the quandaries of changing social systems arising with the French Revolution and the expansion of democracy as well as the increased velocity of modern life that he termed "veloziferisch" (or "of a Luciferian velocity") in his correspondence. His Faust II describes the increased investments in mining and extraction that he experienced firsthand in Weimar during the years he ran the Illmenau mine, ${ }^{29}$ and as he worked with plans to alter and control waterways and drain swamps during the time in Germany documented by David Blackbourn in The Conquest of Nature: Water, Landscape, and the Making of Modern Germany..$^{30}$ In sum, Goethe's works help us understand the transformation of modernity into the Anthropocene and his study of colors reveals most clearly his views on how human beings are part of the physical world, not just masterful manipulators of it.

In terms of his optical studies and colors, the seemingly abstract questions of physics and the nature of light actually show how prescient Goethe was when he insisted that scientific studies address the role of the observer and specifically the human being in relation to nature. In all of his extensive scientific studies on geology, plants, clouds, animals, and light, his work on colors in Farbenlebre most succinctly postulates the fluid, shifting, and interactive aspects of the material world as well as the complex engagements of our daily, moment-to-moment immersion in it. Light and solar energy are the basis of most of the biospheric functions, after all. Additionally, with colors that can emerge from the "eye," the reflection of light on surfaces, or in the chemical composition of all matter, we are in a colorful world that we co-create. Goethe's insight to revolutionary change in our knowledge of colors sounds like Romantic Naturphilosophie unless we place it in our contemporary context of the Anthropocene, in which we are now rather less aesthetically co-creating a new world with a rainbow of industrial shades.

\section{NOTES}

1. Johann Wolfgang von Goethe, Sämtliche Werke. Johann Peter Eckermann. Gespräche mit Goethe, ed. Christoph Michel (Frankfurt am Main: Klassiker, 1999), 320. All translations of Goethe are iny own.

2. See Heather I. Sullivan, "Seeing the Light: Goethe's Märchen as Science-Newton's Science as Fairy Tale," Goethe Yearbook 14 (2007): 103-27.

3. For studies of the New Materialisms, see Diana Coole and Samantha Frost, eds., New Materialisms: Ontology, Agency, and Politics (Durhain, NC: Duke Univ. Press, 2010); Stacy Alaimo and Susan Heknian, eds., Material Feminisms (Bloomington: Indiana Univ. Press, 2008); and Serenella Iovino and Serpil Oppermann, eds., Material Ecocriticism (Bloomington: Indiana Univ. Press, 2014).

4. Johann Wolfgang Goethe, "Der Versuch als Vermittler von Objekt und Subjekt," in Sämtliche Werke. Schriften zur allgemeinen Naturlehre, Geologie und Mineralogie, ed. Wolf von Engelhardt and Manfred Wenzel (Frankfurt an Main: Klassiker, 1989), 26-36, 33. 
5. Johann Wolfgang Goethe, Sämtliche Werke. Zur Farbenlebre, ed. Manfred Wenzel (Frankfurt am Main: Klassiker, 1991), 283.

6. Johann Wolfgang Goethe, Sämtliche Werke. Sprïche in Prosa, ed. Harald Fricke (Frankfurt am Mlain: Klassiker, 1993), 50.

7. See Heather I. Sullivan, "The Ecology of Color: Goethe's Materialist Optics and Ecological Posthumanism," in Material Ecocriticism, ed. Serenella Iovino and Serpil Oppermann (Bloomington: Indiana Univ. Press, 2014), 80-94; and Sullivan, "Material Ecocriticism: Goethe as Case Study," Literatur fiir Leser 3, no. 12 (2013): 147-60.

8. Goethe, Farbenlehre, 31.

9. See the applications of Goethe's views in contemporary science described in the section on "actualization," or "Aktualisierung," in Peter Matussek's edited volume, Goethe und die Verzeitlichung der Natur (Munich: Beck, 1998); in John McCarthy's Remapping Reality: Chaos and Creativity in Science and Literature (Goethe-Nietzsche-Grass) (Amsterdam: Rodopi, 2006); and in David Seamon and Arthur Zajonc's edited volume, Goethe's Way of Science: A Phenomenology of Nature (New York: State Univ. of New York Press, 1998).

10. Goethe, Farbenlebre, 70.

11. Ibid., 172.

12. Sullivan, "Ecology of Color."

13. Johann Wolfgang Goethe, Sämtliche Werke. Schriften zur Farbenlebre 1790-1807, ed. Manfred Wenzel (Frankfurt am Main: Klassiker, 1991), 138.

14. Goethe, Schriften, 23.

15. Goethe, Farbenlebre, 303.

16. Ibid.

17. There are excellent discussions of Goethe's ideas of perception as phenomenology in the Seamon and Zajonc volume, Goethe's Way of Science. Seamon's introduction, "Goethe, Nature, and Phenomenology" (1-14), addresses in particular both Goethe's emphasis on seeing and the subjective aspects of light and color that make up so much of the Farbenlebre. See also the discussions of Goethe's insights into the subjective aspects of perception and observation in Frank Schweitzer's "Naturwissenschaft und Selbsterkenntnis," in Matussek, Verzeitlichung, 382-98. For quantum physics, see Karen Barad, Meeting the Universe Halfway: Quantum Physics and the Entanglement of Matter and Meaning (Durham, NC: Duke Univ. Press, 2007).

18. Victor Lange analyzes Goethe's ideas about "seeing" in "Goethe's Journey in Italy: The School of Seeing," in Antipodische Aufklärungen, ed. Walter Veit (Frankfurt am Main: Lang, 1987), 229-40. See also Peter Salm on Goethe's discussion of perception in The Poem as Plant: A Biological View of Goethe's Faust (Cleveland: Press of Case Western Reserve Univ., 1971).

19. Dennis L. Sepper, in fact, defends Goethe's science and methodology in Goethe contra Newton: Polenics and the Project for a New Science of Color (Cambridge: Cambridge Univ. Press, 1988), noting aspects of color that Newton apparently.did neglect, concluding that "Goethe was on solid ground, and his polemnics point out serious factual and methodological shortcomings in the work of Newton and his followers" (13).

20. See my essays on Goethe's use of colors and the relationship to his critique of Newton: Sullivan, "Seeing the Light," and Heather I. Sullivan, "Ecocriticism, Goethe's Optics and Unterhaltungen deutscher Ausgewanderten: Emergent Forms versus Newtonian 'Constructions," Monatshefte 101, no. 2 (2009): 151-69. For more on the scholarship on Goethe's critique of Nesvton and its relationship to his literary works, see my discussion of his Novelle in Heather I. Sullivan, "The Dynamics of Goethe's Novelle: The Never-Ending Journey to Newton's Burg," 1650-1850: Ideas, Aesthetics, and Inquiries in the Early Modern Era 17 (2008; pub. 2010): 149-67.

21. See Sullivan, "Ecocriticism."

22. Goethe, Eckermann, 116. 
23. For discussions of Goethe's Faust and this debate, see: Simon Richter, "Goethe's Faust and the Ecolinguistics of <Here>," in German Ecocriticism in the Anthropocene, ed. Caroline Schaumann and Heather I. Sullivan (New York: Palgrave Macmillan, 2017), 45-64; Kate Rigby, Topographies of the Sacred: The Poetics of Place in European Romanticism (Charlottesville: Univ. of Virginia Press, 2004); and my essays, Heather I. Sullivan, "Faust's Mountains: An Ecocritical Reading of Goethe's Tragedy and Science," in Heights of Reflection: Mountains in the German Imagination from the Middle Ages to the Tiventy-First Century, ed. Sean Ireton and Caroline Schaumann (Rochester, NY: Camden House, 2012), 116-33; Sullivan, "Affinity Studies and Open Systems: A Nonequilibrium, Ecocritical Reading of Goethe's Faust," in Ecocritical Theory: New European Approaches, ed. Axel Goodbody and Kate Rigby (Charlottesville: Univ. of Virginia Press, 2011), 243-55; and Sullivan, "Ecocriticism, the Elements, and the Ascent/Descent into Weather in Goethe's Faust," Goethe Yearbook 17 (2010): 55-72.

24. On human culture as a geological force, see Dipesh Chakrabarty, "The Climate of History: Four Theses," Critical Inquiry 35 (2009): 197-222; and Bruno Latour, "Agency at the Time of the Anthropocene," New Literary History 45 (2014): 1-18.

25. For information on the currently ongoing extinction event, see Elizabeth Kolbert, The Sixth Extinction: An Unnatural History (New York: Henry Holt, 2014). For introductions to the Anthropocene, see Gabriele Diirbeck, Caroline Schaumann, and Heather I. Sullivan, "Human and Nonhuman Agencies: The Anthropocene, Material Ecocriticism, and the Contributions of Literature," Ecozon@ 6, no. 1 (2015): 118-36; Timothy Clark, Ecocriticism on the Edge: The Anthropocene as a Threshold Concept (London: Bloomsbury, 2015); and Clive Hamilton, Christophe Bonneuil, and François Gemenne, eds., The Anthropocene and the Global Environmental Crisis: Rethinking Modernity in a Newv Epoch (London: Routledge, 2015).

26. For scientific discussions of the Anthropocene, see: Will Steffen, Paul J. Crutzen, and John R. MicNeill, "The Anthropocene: Are I-Iumans Now Overwhelming the Great Forces of Nature," AMBIO: A Journal of the Human Environment 36, no. 8 (2007): 614-21; and Jan Zalasiewicz, Mark Williams, Will Steffen, and Paul Josef Crutzen, "The New World of the Anthropocene:The Anthropocene, Following the Lost World of the Holocene, Holds Challenges for Both Science and Society," Environmental Science \& Technology 44, no. 7 (2010): 2228-31.

27. For information on the debate regarding the Anthropocene's starting point at 1945, see Jan Zalasiewicz, Mark William, et al., "Are We Now Living in the Anthropocene?," GSA Today 18, no. 2 (2008): 4-8. On the impact of agriculture and the ensuing mass plant extinctions, see Todd J. Braje and Jon M. Erlandson, "Human Acceleration of Animal and Plant Extinctions: A Late Pleistocene, Holocene, and Anthropocene Continuum," Anthropocene 4 (2013): 14-23.

28. Paul Crutzen and Eugene F. Stoermer, "The Anthropocene," Global Change Newsletter 41 (2000): 17-18; Chakrabarty, Climate of History; Rob Nixon, Slow Violence and the Environmentalism of the Poor (Cambridge, MA: Harvard Univ. Press, 2011); and Timothy Morton, "How I Learned to Stop Worrying and Love the Term "Anthropocene," Cambridge Journal of Postcolonial Literary Inquiry 1 , no. 2 (2014): 257-64.

29. See Goethe's documents on running the mine as part of the "Bergwerkskommission": Johann Wolfgang Goethe, Sämtliche Werke. AmtlicheSchriften Teil I, ed. Reinhard Kluge (Frankfurt am Main: Klassiker, 1998).

30. David Blackbourn, The Conquest of Nature: Water, Landscape, and the Making of Modern Germany (New York: Norton, 2007). 